\title{
Shu-Huang Ou, 1912 to 2001
}

\author{
T. W. Mew and Colin McClung
}

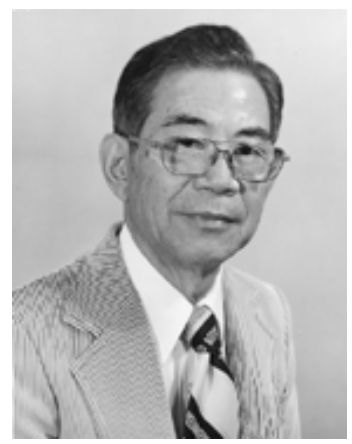

"SH" Ou died peacefully on 17 April 2001, at his home in Palo Alto, CA, just a few days after his 89th birthday. His wife of 60 years, Jane (Chang Tze-Hwa), died 3 years earlier on 13 May. He left two sons, Tungching and Shukong, their spouses Annie (Wang) and Joan (O'Connor), and grandchildren Tunhow, Tunlin, Katherine Mayling, and Michael Tunhwa. He also left relatives in mainland China.

SH lived a full life. He traveled around the world and accomplished many goals. With a Ph.D. from the University of Wisconsin in 1945, he went to Iraq as a visiting scientist until its revolution, worked as a botanist for the JCRR (Joint Commission for Rural Reconstruction) in Taiwan, then for the United Nations Food and Agriculture Organization in Thailand, and later for the International Rice Research Institute (IRRI) in the Philippines as principal plant pathologist. He guided many students toward their advanced degrees.

In 1984, he wrote a prefatory chapter for the Annual Review of Phytopathology, where he indicated that most of his 50 working years as a plant pathologist were during the turbulent period of civil wars and World War II. In the early years, his research was often disrupted and changed to enable him to pursue his career goal. Not until he joined IRRI did he have enough time to do what he did best-plant pathology research. In that introductory chapter, SH traced the history of rice pathology research in the tropics. "The number of plant pathologists has been insufficient to cope with important disease problems," he said. "Mistakes have been made through prejudice, misconception, and blind faith in old ideas and untested new ones." SH had joined IRRI with a mission to uplift research on rice diseases to a new scientific standard in the tropics and, by so doing, help solve rice production problems. Pursuing that goal also opened up new horizons in research on rice diseases and increased scientific exchange between the East and the West. He felt that research in the East needed to be exposed to peers globally. SH did exactly that. He did pioneer research on tropical rice diseases and much of his early research is classic in plant pathology.

Before the establishment of IRRI, most rice virus diseases were considered physiological disorders. SH's most remarkable achievement was using simple yet well-designed scientific procedures to establish the etiology of rice virus diseases in tropical Asia, such as rice tungro, grassy stunt, and orange leaf (later verified to be caused by mycoplasma). The identification of "mentek" and "penyakit merah" as tungro virus disease is classic. Many plant pathologists, both young and old, remember this work. Using simple cage experiments, SH and his staff proved that these maladies were identical and transmissible through leafhoppers.

SH organized the first international symposium on rice blast research in 1963 that brought together plant pathologists and plant

Publication no. P-2001-1031-010 breeders to work on laying the foundation of resistance breeding, earmarked as one of IRRI's achievements in the early years leading to the Green Revolution. Following the symposium, the international rice blast nursery was organized as a means to test varietal resistance of rice germ plasm suitable for use in resistance breeding in the different rice-growing countries, and to document the diversity of the rice blast pathogen. Later, he established a set of international differential varieties for pathogen race identification. This was the first international blast nursery, which later spread to more than 30 rice-growing countries. The project set up a model of international collaboration and opened up potential areas of geopathology. SH also led the way for future collaboration.

He wrote a comprehensive survey titled "Rice Diseases," first published in 1972, which was updated in a second edition in 1985 after he retired from IRRI and became adjunct professor at the University of Wisconsin, Madison. It is the acknowledged reference work on the subject and can be found in libraries worldwide (ISBN 0851985450). SH requested the lowest possible price for the book so it would be affordable to scientists who needed it.

SH struck many as a simple person, but he was a great teacher with strong traditional Asian values. One of his former colleagues at IRRI, Mr. Fausto Nuque, after learning about his death, wrote to Dr. Tom Mew: "Dr. Ou's food for thought and worthy advice helped me steer my fate in the ocean of uncertainty. For all the support and magnanimity he has extended to me, I am forever grateful to him." SH treated his staff not just as research assistants, but as his children. He showed them how to do scientific research and how to be responsible citizens. Mr. Nuque recalled his first day at work when $\mathrm{SH}$ took him to the seed multiplication plots. In the rice paddies, "Dr. Ou folded his long pants and waded to the first irrigated field plot to record his observations on the rice plant. Following his example, I also folded my pants and went to help him record our observations about rice diseases for the next 3 days. Later, Dr. Ou also informed me that during my first day (at work), in the field, when we waded in the rice paddies, his main objective was to ascertain whether or not I was really a hardworking person not afraid to work in the mud."

SH believed that there was no shortcut to good research but hard work. When Dr. Mew first joined IRRI, SH said, "Tom, good observation is important for good research. You cannot make a good observation if you don't work with your rice plants closely."

Two and a half years ago, $\mathrm{SH}$ was diagnosed with liver cancer, which ultimately took his life. Nevertheless, he led an active life until about 6 months ago, taking walks in the park, driving to the store, having meals with friends, and catching the latest news.

At all times, $\mathrm{SH}$ believed that a good education combined with hard work would be rewarded. Education was a goal that was worth achieving even if hardships were found along the way. He believed that education was obtained beyond books and classes.

$\mathrm{SH}$ left a mark on rice research and a deeper mark where it matters most-in the hearts of those people he touched in his lifetime with love and sincerity. He will be deeply missed by friends and family. 